\title{
Traumatic brain injuries induced pituitary dysfunction: a call for algorithms
}

\author{
Aleksandra Gilis-Januszewska ${ }^{1,2, *}$, Łukasz Kluczyński ${ }^{1,2, *}$ and Alicja Hubalewska-Dydejczyk ${ }^{1,2}$ \\ ${ }^{1}$ Chair and Department of Endocrinology, Jagiellonian University Medical College, Krakow, Poland \\ ${ }^{2}$ Endocrinology Department, University Hospital in Krakow, Krakow, Poland
}

Correspondence should be addressed to Ł Kluczyński: kuki-10@02.pl

*(A Gilis-Januszewska and $Ł$ Kluczyński contributed equally to this work)

A Hubalewska-Dydejczyk is a member of the editorial board of Endocrine Connections. She was not involved in the editorial or peer-review process for this paper, on which she is listed as an author.

\begin{abstract}
Traumatic brain injury affects many people each year, resulting in a serious burden of devastating health consequences. Motor-vehicle and work-related accidents, falls, assaults, as well as sport activities are the most common causes of traumatic brain injuries. Consequently, they may lead to permanent or transient pituitary insufficiency that causes adverse changes in body composition, worrisome metabolic function, reduced bone density, and a significant decrease in one's quality of life. The prevalence of posttraumatic hypopituitarism is difficult to determine, and the exact mechanisms lying behind it remain unclear. Several probable hypotheses have been suggested. The diagnosis of pituitary dysfunction is very challenging both due to the common occurrence of brain injuries, the subtle character of clinical manifestations, the variable course of the disease, as well as the lack of proper diagnostic algorithms. Insufficiency of somatotropic axis is the most common abnormality, followed by presence of hypogonadism, hypothyroidism, hypocortisolism, and diabetes insipidus. The purpose of this review is to summarize the current state of knowledge about post-traumatic hypopituitarism. Moreover, based on available data and on our own clinical experience, we suggest an algorithm for the evaluation of post-traumatic hypopituitarism. In addition, well-designed studies are needed to further investigate the pathophysiology, epidemiology, and timing of pituitary dysfunction after a traumatic brain injury with the purpose of establishing appropriate standards of care.
\end{abstract}

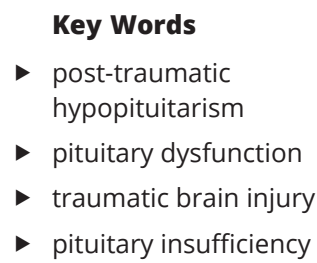

\section{Introduction and epidemiology}

Traumatic brain injury (TBI) is commonly defined as any brain pathology caused by an external force. TBI, sometimes referred to as a 'silent epidemic', affects about 69 million people each year, occurs commonly in young adults, and causes a serious burden of devastating health consequences $(1,2)$. The Glasgow Coma Scale (GCS) is used to divide TBI into mild (concussion, 13-15 points), moderate (9-12 points), and severe (3-8 points). Another classification of TBI distinguishes between closed (blunt) and open (penetrating) traumas (3); the latter are always severe. It is difficult to determine the actual prevalence and incidence of TBI. Numerous patients with mild injuries neglect further diagnostics or who are treated at primary healthcare centers do not count in hospital statistics. A study based on data from 13 European countries estimated that the incidence of TBI incidence is 235 per 100,000 per year (4) and another one reported 506 TBI cases per 100,000 in the USA (5). The recent systematic
This work is licensed under a Creative Commons Attribution-NonCommercial-NoDerivatives 4.0 Internationad bicense.ifica.com at 04/26/2023 08:22:08AM 
review by Nguyen et al. concluded that the pooled annual incidence rate of TBI is 349 per 100,000 person-years. Mild, moderate, and severe TBI pooled annual incidence were 224, 23, and 13 per 100,000, respectively (6). In Europe, annual mortality rate associated with TBI was estimated to be 15 per 100,000 (4). Head traumas are twice as common in men as in women (7). Falls, motor-vehicle and workrelated accidents, assaults, as well as sport activities are the most typical causes of brain injuries. Pituitary dysfunction resulting as a consequence of brain injury is not a new phenomenon - the first article illustrating the matter was published in 1918 (8). Nowadays, the topic is gaining more and more attention due to new reports of pituitary insufficiency caused by relatively mild, repetitive brain traumas. The incidence of post-traumatic hypopituitarism (PTHP) is likely underestimated. Based on the review of literature published between May 2000 and October 2018, Benvenga defined that PTHP accounts for $7.2 \%$ of the total cases of hypopituitarism (9). The prevalence of PTHP among patients with a history of TBI is estimated to be $15-68 \%(10,11,12)$. Symptoms may present at any time after the inflicting trauma (5). The severity of brain injuries corresponds to the development of the observed deficiencies: PTHP was diagnosed in $16.8 \%, 10.9 \%$, and $35.5 \%$ of patients with mild, moderate, and severe TBI, respectively $(10,13)$. Insufficiency of somatotropic axis is the most common abnormality, followed by presence of hypogonadism, hypothyroidism, hypocortisolism, and diabetes insipidus $(14,15,16)$. Pituitary dysfunction after a traumatic brain injury is usually transient and may resolve or regain its functional abilities within 1 to 3 years; however, it can also present itself clinically or develop many years after the initial TBI (17).

\section{Pathogenesis}

The exact mechanism of post-traumatic hypopituitarism remains unclear. Several probable hypotheses have been suggested. The unique location and the intricate vascularization of the pituitary gland plays a key role in the pathogenesis of post-traumatic hypopituitarism (18, 19). Shearing forces during brain injuries may damage the vessels supplying the pituitary gland and lead to the necrosis of the pituitary lobes. Similar effect results from compression due to the increased intracranial pressure $(20,21,22)$. Stalk amputation or stalk displacement caused by mass effect may influence the blood supply to the pituitary lobes (21). Moreover, general hypovolemia provides alternative explanations to pituitary gland ischemia. Sheehan syndrome is a well-known consequence of traumatic labor involving significant blood loss (23). Additionally, pituitary apoplexy has been reported in a previously healthy adolescent patient after serious thoracic trauma requiring surgery due to the dissection of descending aorta (24). Furthermore, thyroidectomy (25), CABG (26), or lung resection (27) has been shown to be probable causes that lead to hypopituitarism in patients with preexisting pituitary enlargement or adenoma.

The impaired vascular supply hypothesis explains the observed hormonal abnormalities seen in post-traumatic hypopituitarism. It correlates well with the distribution of somatotrophs and gonadotrophs which are located in the lateral part of the anterior pituitary lobe and pars tuberalis, respectively - areas susceptible to ischemia due to portal vessels blood supply (19). The central portion of the gland comprising cortico- and thyrotrophs is supplied mainly by short hypophyseal portal vessels and, thanks to that, remains less susceptible to ischemic traumas $(28,29)$. Benvenga et al. confirmed MRI changes of the hypothalamus/pituitary area in $93 \%$ patients who suffered from post-traumatic pituitary dysfunction (30). Fatal TBI cases were associated with pituitary infarction in up to $43 \%$ of autopsies (20). The hypothalamus is not typically injured in brain trauma; however, increased intracranial pressure may play a role in the apoptosis of cells in the hippocampus, hypothalamus, and the pituitary gland (31).

The impact forces generated by traumatic brain injury may directly harm the pituitary gland, especially its stalk, and result in abnormal hormone production $(32,33,34)$. Head traumas may result in axonal brain injury - subtle changes to the nerve tissue, detectable only with the use of the newest visualizing techniques (35). Experimental studies in animals suggest two additional alternative mechanisms of PTHP. The first one describes inflammation and astrocytosis in hypothalamus-pituitary area (36), while the second focuses on tanycytes, the barrier cells of the third ventricle, whose inappropriate junctions may impact the hypothalamus function (37).

In recent years, more attention has been put to the link between PTHP and autoimmunity. TBI may induce an inflammation in the nervous system $(38,39)$ as well as an increase in the permeability of blood-brain barrier, resulting in the excessive exposure of pituitary and hypothalamic antigens (40). The presence of autoantibodies against pituitary (APA) and hypothalamus (AHA) was reported in patients with post-traumatic hypopituitarism even 5 years after the initial diagnosis (41). Tanriverdi et al. found APA in $44.8 \%$ of patients 
3 years after they sustained their brain injury. No antibodies were detected in the control group whose patients were matched by age and gender (42). Higher values of APA in post TBI patients were associated with a more frequent development of pituitary insufficiency, while negative antibody titers were associated with a recovery of the pituitary function in a 5-year prospective study $(39,43)$. Antibodies against pituitary gland and hypothalamus (in $22.9 \%$ and $21.3 \%$ of cases, respectively) were found in a study of 61 professional boxers. Their presence was associated with a higher incidence of hypopituitarism $(46.2 \%$ vs $10.4 \%)$ (44). Persistent hypopituitarism in Sheehan's syndrome may have autoimmune background as well, since APA and AHA have been detected in women many years after their initial diagnosis (45). Further research is needed to define the exact significance of autoimmune reactions in post-traumatic insufficiency of the pituitary gland. The presence of specific antibodies involved in the development and preservation of pituitary dysfunction can potentially help identify highrisk patients and will allow the development of proper diagnostic and treatment algorithms (5).

Interestingly, a reduced risk of PTHP was described in patients with apolipoprotein E3 (APO E3) genotype. APO E3 is a protective protein with confirmed neuronal anti-inflammatory actions (42). These findings suggest that complex pathophysiology of PTHP may also have a genetic component. In addition, apolipoprotein E4 was proved to have a neuroprotective effect in patients with a history of concussion $(46,47)$.

Recent research reports that pituitary deficiency after TBI may be also related to an altered miRNA expression profile. Taheri et al. found that miR-126-3p and miR-3610 were detected in the serum of patients who developed hypopituitarism on the 1st, 7 th, and 28th days and in the 5th year following TBI. Further studies on examining the relationship between various miRNA and pituitary deficiency can help determine the role of specific genes controlled by miRNA. Therefore, miRNA may be used as potential indicators for the early diagnosis of patients who are at a higher risk of developing pituitary deficiency after TBI (48).

\section{Sport-induced hypopituitarism}

Sport-induced hypopituitarism (SIHP) is a relatively new endocrine problem. Little is known about the exact incidence of SIHP due to the difficult recognition of the cases. Specifically, contact sports, as well as equestrian and winter sports, and any sports-related fall or injury, are the most common activities that lead to brain injuries. This suggests that mild repetitive brain injuries sustained throughout an athlete's career may accumulate to the magnitude of a severe trauma and lead to pituitary gland dysfunction $(49,50,51,52)$. Worldwide, there is a growing popularity of boxing and kickboxing, both of which are known to cause repetitive head trauma and thus pituitary insufficiency (53).

In the study of 61 boxers, Tanriverdi found growth hormone deficiency in $15 \%$ of them (which correlated with a decreased pituitary volume) and also ACTH deficiency in $8 \%$ of the participants (42). The same author reported decreased IGF-1 levels in amateur kickboxers; $22 \%$ and $9 \%$ of them were diagnosed with GH and ACTH deficiency, respectively (54). In another study, Kelestimur et al. described a negative correlation between stimulated GH peak and both the number of fights and the time spent boxing (53).

Football players may be affected by SIHP as well. Hormonal deficiency has been reported in $23.5 \%$ of evaluated patients (14.7\% presented with growth hormone deficiency, $4.4 \%$ presented with hypogonadism, and $4.4 \%$ presented with abnormalities in both) (55). The literature also describes anecdotal cases of SIHP in swimmers and soccer players $(56,57)$.

\section{Blast-related hypopituitarism}

The relatively high prevalence of chronic hypopituitarism among military veterans attracted more attention to blast injuries as a possible culprit. Wilkinson et al. evaluated 26 veterans with a history of blast exposure, among which 11 (42\%) presented hormonal abnormalities - somatotropic and gonadal axes being most affected (58). The potential mechanism is likely associated with the blastwave and the secondary injuries that may elicit cell destruction, vascular changes, and diffuse axonal injuries in the pituitary gland $(59,60)$. Growth hormone deficiency was confirmed by the glucagon stimulation test in $25 \%$ of 20 soldiers who suffered mild TBI ( $85 \%$ of them as a result of blast injury) (61). In another study, Undurti et al. compared 39 male soldiers with a history of blast related TBI and 20 soldiers who had not experienced explosion lesions (both groups were deployed under similar conditions). Hormonal abnormalities were detected in 31\% and 15\% of participants, respectively, with growth hormone deficit being the most common abnormality (62). Baxter et al. documented a significantly higher ratio (32\%) of anterior

This work is licensed under a Creative Commons Attribution-NonCommercial-NoDerivatives 4.0 Internationab ticense.ifica com at $04 / 26 / 2023$ 08:22:08AM 
pituitary dysfunction in patients with a history of direct blast exposure relative to patients with non-blast-TBI $(2,6 \%)$. The study was extended to include an assessment of the hypothalamic-pituitary area on MRI studies, in which brain scans did not reveal any pathological changes in post-blast patients (63).

In addition to the previously mentioned changes, blast related hypopituitarism is also associated with a decreased quality of life, a higher rate of depression, and post-traumatic stress disorders $(61,62)$.

\section{Children and adolescents}

Posttraumatic hypopituitarism in children is uncommon. Again, it is difficult to establish its prevalence. Personier et al. estimated the incidence of PTHP in children at $8 \%$ (64). Two studies, one including 198 subjects younger than 2 years of age and a second study with 37 children under 6 years of age did not report any evidence of pituitary dysfunction $(65,66)$. In older children, growth hormone deficiency was present in about $34 \%$ of patients 1 year after an injury. Regular auxological assessments are important in the early detection of the condition (67) as well as any records of adverse changes in body habitus, as $15 \%$ of children with TBI were reported to be overweight during their final evaluation in a study of Jourdan et al. (68). In a systematic review of literature, Soliman et al. estimated that the rates of ACTH, LH/FSH, GH, and TSH deficiencies in children with TBI were $2-43 \%, 6-16 \%$, $6-48 \%$, and $2-33 \%$, respectively (69). Lastly, repetitive TBI in young patients may also have a significant influence on subsequent reproductive complications and physical growth $(70,71,72)$.

\section{Presentation}

Traumatic brain injury is a compound disease process beginning at the moment of trauma and evolving with time (73). The development of post-traumatic hypopituitarism can vary and may overlap with nonspecific symptoms resulting from the injury. Thus, the diagnosis is often challenging. The delay in the disease recognition and the severity of the hormonal deficits may determine the clinical presentation (74). The symptoms resemble other forms of hypopituitarism.

PTHP results in a higher morbidity and mortality (75). The survivors face decreased quality of life, adverse changes in their body composition, abnormal metabolic tests, and reduced bone density $(76,77)$. Recent studies attribute more attention to cognitive and affective impairment among the patients, not only due to the brain injury itself but also due to PTHP (75). Neuropsychiatric symptoms range from mild to severe and may significantly affect patients' function in the society (74). Due to the fact that each anterior pituitary lobe axis is involved, hormone replacement therapy may improve the recovery of cognitive functions $(78,79,80)$. Thyroid hormones were found to play a role in neurogenesis in rats (81). Testosterone substitution may improve memory in patients with hypogonadism (82) and protect from an increased risk of Alzheimer's disease (83). The influence of estrogen therapy on cognitive function is not fully understood (84). Kelly et al. confirmed that patients with post-traumatic GH deficiency (GHD) have more severe cognitive impairment than those with normal values of GH (85). Several studies reported more frequent deficits in memory and attention, worse reaction-times, as well as emotional problems in subjects with $\operatorname{GHD}(86,87)$. In contrary, Pavlovic et al. did not detect significant differences between post-traumatic patients with and without GHD (87). Lower IGF-1 levels were associated with worse visual memory (88) and increased risk of Alzheimer's disease (89). Due to the similarity of symptoms, there is a discussion about the contribution of post-TBI hormonal abnormalities to the clinical presentation of PTSD (62). Similar psychiatric alterations were found in TBI patients with/without PTHP, but therapy with growth hormone improved mental function $(88,89,90)$.

Another important abnormality in patients with PTHP is related to changes in metabolic profile. Increased BMI and higher values of total cholesterol as well as its LDL fraction were reported in subjects with PTHP (75). Patients with anterior pituitary lobe hormonal deficits post TBI were reported to have increased blood glucose, insulin resistance, dyslipidemia, higher waist circumference, and increased abdominal fat and leptin values $(76,91)$. The probable mechanisms beyond weight gain in patients with PTHP include altered function of hypothalamic nuclei, which control energy homeostasis, changes in circadian rhythms, mood alterations, and bodily response to medications (73).

\section{Acute stage}

The first 2 weeks following trauma are considered as an acute-phase. Hannon et al. defined the prevalence of pituitary dysfunction in $78 \%$ of patients with history of

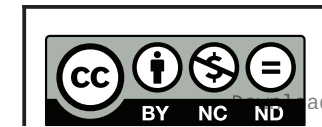

This work is licensed under a Creative Commons Attribution-NonCommercial-NoDerivatives 4.0 Internationab bicense.ifica. com at 04/26/2023 08:22:08AM 
traumatic brain injury (92). Possible physiological changes, adaptive changes related to their critical condition, or difficulties in performing dynamic testing in these patients make the assessment of hormonal profile challenging. Deficits in gonadotropin and growth hormone are the most common changes among patients in the acute phase of TBI. However, it is absolutely crucial to detect any signs of adrenal insufficiency. No risk factors for ACTH deficits have been identified so far. The condition was found in $78 \%$ of hospitalized patients within 10 days of moderate and severe TBI (based on cortisol level lower than $11 \mu \mathrm{g} / \mathrm{dL}$ ) (92). In another study, Bensalah et al. evaluated 200 patients during the first week after they sustained a TBI. He concluded that $2.8 \%, 21 \%$, and $37 \%$ of the patients presented with a cortisol level below 3,10 , and $15 \mu \mathrm{g} / \mathrm{dL}$, respectively (93). Patients with secondary hypocortisolism are known to require a higher level of vasopressors and often suffer from a higher mortality rate $(92,94)$. Since hypoadrenalism is potentially life-threatening, hormone replacement therapy should be introduced immediately. It should be noted that cortisolemia may be affected by drugs (i.e. etomidate, propofol) that were administered in the intensive care units (94). Various prolactin levels were reported in patients with PTHP - hyperprolactinemia may be associated with a reduced inhibiting action of dopamine, often caused by stalk compression and/or physiological reaction to stress (95). Other changes such as decreased thyroxin and antidiuretic hormones may also be detected (96). These changes are usually transient and resolve within 3-12 months $(97,98,99)$. Thus, a number of authors cast doubt on the benefits of acute-phase hormonal therapy $(10,100)$. Impaired vasopressin secretion (central diabetes insipidus - CDI as well as syndrome of inappropriate antidiuretic hormone hypersecretion - SIADH) in patients with TBI are usually transient, yet sometimes the recovery period may last months (101). Central Diabetes Insipidus occurs in $16-28 \%$ of patients with TBI $(30,101)$ and correlates with the severity of the trauma, the resulting cerebral edema, and the mortality rate $(82,102)$. Early detection of CDI or SIADH is essential in patients presenting with severed neurological function, where hydro-electrolytic imbalance may be life-threatening (103).

\section{Chronic stage}

Due to the challenges in evaluating pituitary function during the acute phase post TBI as well as the multitude of dynamic changes that follow the injury, patients should be reassessed in follow-up studies (5). The chronic-phase of the PTHP is said to begin 3 months after the initial trauma. Data about the prevalence of the condition are unclear. Between 5.4 to $76.4 \%$ of patients present with long-term pituitary hormone abnormalities (104). The wide range in presentation is likely due to the significant differences in the diagnostic criteria. It should be underlined that basic hormonal values, without dynamic tests, may lead to inappropriate description of the pituitary function. Similar to the acute phase, growth hormone deficiency and hypogonadism are the two most common anomalies seen in the chronic phase. Long-term ACTH and TSH deficits are relatively rare (less than $10 \%$ of cases) (31). These results are consistent with the Taniverdi study, where $\mathrm{GH}, \mathrm{ACTH}$ and $\mathrm{LH} / \mathrm{FSH}$ deficits were found in $28 \%$, $4 \%$, and $4 \%$, respectively, 5 years post initial trauma (43). Central diabetes insipidus is persistent in $7 \%$ of patients in long-term observational studies (101).

\section{Diagnostic approach}

High occurrence of traumatic brain injuries makes routine endocrinological screening controversial. British Neurotrauma Group guidelines recommend performing a hormonal assessment in patients hospitalized for more than $48 \mathrm{~h}$ following a TBI (31). Patients with a mild TBI should be screened if they present with symptoms of hypopituitarism (105). According to the suggested algorithm, first post-acute phase evaluation should be performed between 3 and 6 months after the injury (31, $100,106)$. Thyroid and gonadal axes assessment includes measurements of TSH, fT4, gonadotropins, estrogens in women, and testosterone in men. Morning cortisol level greater than $18 \mathrm{ug} / \mathrm{dL}$ indicates proper ACTH/adrenal function, while a concentration lower than $3 \mu \mathrm{g} / \mathrm{dL}$ is a marker of hypoadrenalism $(31,107)$. Cortisol values between 3 and $18 \mu \mathrm{g} / \mathrm{dL}$ require further investigation through stimulating tests, of which short synacthen test is commonly used (108). Somatotropic axis evaluation should be postponed until 1 year after the injury, with the exception of children, who may require earlier assessment. In patients with multi-hormonal abnormalities, low IGF-1 levels may suggest growth hormone deficiency (GHD) (105). Various tests can confirm GHD with a high level of confidence $(109,110)$. The possibility of persistent CDI should also be taken into consideration (106).

There are valuable algorithms that help predict clinical outcome of severe traumatic brain injury. The IMPACT calculator assesses age, the motor score component

This work is licensed under a Creative Commons Attribution-NonCommercial-NoDerivatives 4.0 Internationab bicense.ifica .com at 04/26/2023 08:22:08AM 
of GCS, and the pupillary reaction. The expanded version, including in addition levels of glial fibrillary acidic protein, ubiquitin C-terminal hydrolase-L1, and $\alpha$ II-spectrin breakdown products measured in the serum and the cerebrospinal fluid of patients with TBI, correlates with a 6-month mortality rate (111). This information may be an invaluable prognostic model; however, it does not refer specifically to the posttraumatic pituitary function. Moreover, the study of the previously mentioned biomarkers is not widely available in clinical practice.

Based on the current available literature and on our own experience, we suggest a novel algorithm for the evaluation of post-traumatic hypopituitarism (Fig. 1).

\section{Imaging}

Radiological presentation of patients with a history of traumatic brain injury varies significantly. Certain changes, especially related to mild TBI, may be undetectable using routine imaging (35). Although CT is usually more easily available in acute conditions and provides better visualization of skull fractures, MRI is far superior for assessment of intracranial hematomas, contusion, and shearing injuries, with an estimated sensitivity of $96.4 \%$ (compared to a sensitivity of $63.4 \%$ for CT studies) (112, 113). Kelly et al. documented that diffuse brain swelling may be a predictive factor for post-traumatic pituitary dysfunction (114). The association between

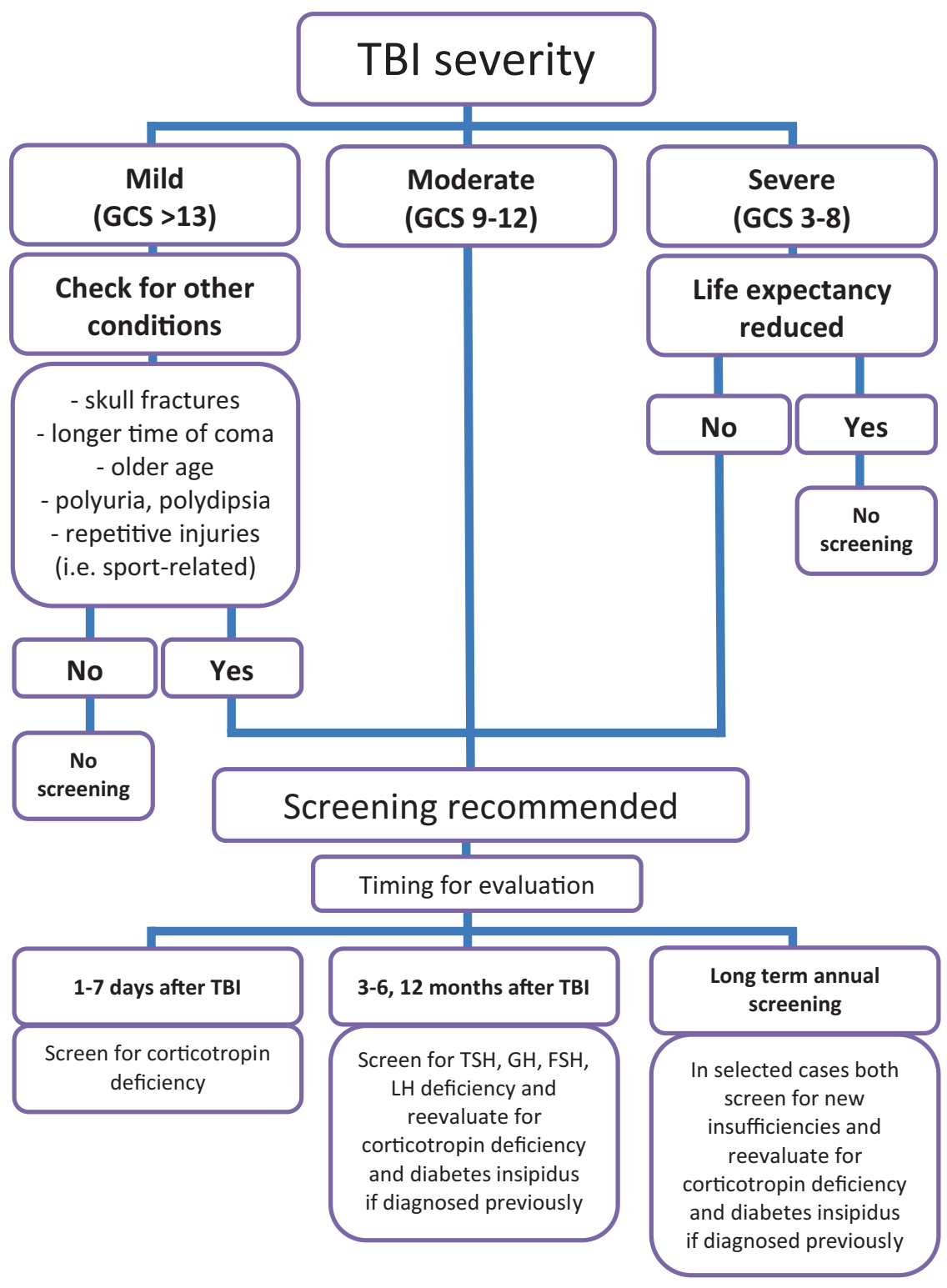

Figure 1

Proposed algorithm for diagnosis of pituitary function after traumatic brain injury (data from Glynn \& Agha (105), Czeiter et al. (111),

Fernandez-Rodriguez et al. (126), and Herrmann et al. (127)). TBI, traumatic brain injury; GCS, Glasgow coma scale; TSH, thyroid-stimulating hormone; $\mathrm{GH}$, growth hormone; FSH, follicle stimulating hormone; LH, luteinizing hormone.
This work is licensed under a Creative Commons Attribution-NonCommercial-NoDerivatives 4.0 elnternationad ticense ifica.com at 04/26/2023 08:22:08AM 
basal skull fractures or diffuse axonal injury and PTHP was identified by Schneider et al. (115). In addition, patients with PTHP show more chronic abnormalities in magnetic resonance $(16,116)$. Relative to patients who suffered a TBI but did not present with pituitary dysfunction, microstructural damages of the pituitary gland tissues in patients with PTHP present as decreased water diffusion on MRI studies (117). Specifically, a reduction in the pituitary size may result from the necrosis and/or intracranial hypertension $(16,117)$. Decreased pituitary volume was also seen in a professional boxer who suffered from GHD when compared to a professional boxer whose GH were within the normal range (118). MRI images in further studies may reveal atypical enhancement of the pituitary gland, an empty sella, and/or abnormal pituitary lobe signal (119).

\section{Treatment}

The cornerstone of treatment of patients with posttraumatic hypopituitarism is hormonal replacement. The general principles of the treatment resemble those used in other forms of pituitary dysfunction (120). Deficits in GH, TSH, and LH/FSH are usually transient, and there is no data in the current literature regarding the benefits of hormonal replacement in the acute phase $(10,101)$. In contrast, decreased $\mathrm{ACTH} /$ cortisol level should be detected as soon as possible, to ensure appropriate administration of hydrocortisone. Patients who present with ACTH deficiency symptoms should first be stabilized. Next, they should be re-tested, to determine whether they have a persistent hypocortisolism (121, 122). Proper hormonal replacement has a potential to reverse the symptoms and to reduce the risk associated with hypocortisolism (10). Growth hormone substitution in the chronic phase improves cognitive function, body composition, and quality of life $(91,123)$. In long term studies, even patients without detectable abnormalities in their hormonal profile should be cognizant of possible worrisome signs and symptoms of hypopituitarism (14).

\section{Prognosis}

A systematic review by Tanriverdi et al. concluded that the predictive factors of long-term PTHP include: the presence of intracranial hypertension, the initial severity of brain trauma on the CT scan, the magnitude of diffuse axonal injury, the age of the patient, duration of hospitalization in an intensive care unit, the presence of rapidly changing hormone values, any basal skull fractures, and the presence of anti-pituitary or anti-hypothalamic antibodies (121). Persistent GH deficiency is also a negative predictor of one's recovery from TBI $(10,34)$. In another study, Hannon et al. emphasized the occurrence of acutephase cortisol deficits as a predictor of mortality and chronic hypopituitarism (93). In the majority of cases, PTHP is transient - probably due to the fact that some pathological changes (i.e. hypoperfusion, intracranial hypertension, and edema) have a reversible character. The possible regeneration of hypophyseal vascularization should be taken into consideration as well (21). About $55 \%$ of patients with PTHP recover within 3 months, and $74-85 \%$ of patients recover within 1 year (29). Klose et al. reported a similar rate of improvement, documenting $76 \%$ of patients affected by early pituitary dysfunction and only $11 \% 1$ year after their TBI (124). The recovery of LH/FSH function was seen in most cases, followed by GH and ACTH (125). In contrast, Tanriverdi et al. reported that $50 \%$ of 52 patients were diagnosed with new hormonal abnormalities a year after their TBI. These subjects were re-tested 5 years later and $24 \%$ of them presented with chronic hypopituitarism (98). However, the prognostic markers and the underlying recovery mechanism from a hypopituitarism state, either immediately after TBI or after a certain period of time, have not yet been determined. As mentioned earlier, glial fibrillary acidic protein, ubiquitin C-terminal hydrolase-L1, and $\alpha$ IIspectrin breakdown product (SBDP145) are intensively investigated as potential elements of algorithms used for outcome prediction in patients after TBI (111).

Further research on the identification of specific antibodies, MiRNAs, neuro anti-inflammatory proteins, and other markers should be carried on, with the ultimate goal of developing indicators for the early diagnosis of patients who may potentially recover or develop pituitary deficiency after sustaining a TBI $(42,46,48)$.

\section{Conclusions}

Traumatic brain injury management is a significant challenge for the healthcare systems in many countries. Lack of proper algorithms leads to the overlooking of post-traumatic hypopituitarism, which may have a great impact on patients' health status and their quality of life. Specific screening methods should be created to identify patients who sustained traumatic brain injuries and who require further observation and/or treatment.

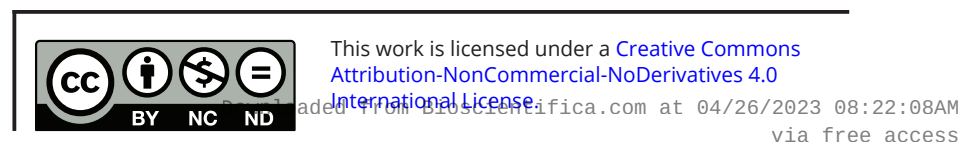


Further research is needed to explain the exact mechanisms responsible for pituitary dysfunction resulting from traumatic brain injury. Ultimately, these studies will help healthcare workers prevent PTHP and prepare them to provide optimal treatment to patients with these complications.

\section{Declaration of interest}

Alicja Hubalewska-Dydejczyk is a Senior Editor for Endocrine Connections. She was not involved in the editorial or peer-review process for this paper, on which she is listed as an author. The other authors have nothing to disclose.

\section{Funding}

This review did not receive any specific grant from any funding agency in the public, commercial, or not-for-profit sector.

\section{References}

1 Dewan MC, Rattani A, Gupta S, Baticulon RE, Hung YC, Punchak M, Agrawal A, Adeleye AO, Shrime MG, Rubiano AM, et al. Estimating the global incidence of traumatic brain injury. Journal of Neurosurgery 2018130 1055-1064. (https://doi.org/10.3171/2017.10.JNS17352)

2 Peeters W, van den Brande R, Polinder S, Brazinova A, Steyerberg EW, Lingsma HF \& Maas AIR. Epidemiology of traumatic brain injury in Europe. Acta Neurochirurgica 2015157 1683-1696. (https://doi. org/10.1007/s00701-015-2512-7)

3 Blennow K, Brody DL, Kochanek PM, Levin H, McKee A, Ribbers GM, Yaffe K \& Zetterberg H. Traumatic brain injuries. Nature Reviews: Disease Primers 20162 16084. (https://doi.org/10.1038/nrdp.2016.84)

4 Tagliaferri F, Compagnone C, Korsic M, Servadei F \& Kraus JA. Systematic review of brain injury epidemiology in Europe. Acta Neurochirurgica 2006148 255-268; discussion 268. (https://doi. org/10.1007/s00701-005-0651-y)

5 De Bellis A, Bellastella G, Maiorino MI, Costantino A, Cirillo P, Longo M, Pernice V, Bellastella A \& Esposito K. The role of autoimmunity in pituitary dysfunction due to traumatic brain injury. Pituitary 201922 236-248. (https://doi.org/10.1007/s11102-019. 00953-z)

6 Nguyen R, Fiest KM, McChesney J, Kwon CS, Jette N, Frolkis AD, Atta C, Mah S, Dhaliwal H, Reid A, et al. The international incidence of traumatic brain injury: a systematic review and meta-analysis. Canadian Journal of Neurological Sciences 201643 774-785. (https:// doi.org/10.1017/cjn.2016.290)

7 Langlois JA, Rutland-Brown W \& Wald MM. The epidemiology and impact of traumatic brain injury: a brief overview. Journal of Head Trauma Rehabilitation 200621 375-378. (https://doi. org/10.1097/00001199-200609000-00001)

8 Cyran E. Hypophysenschadigung durch Schadelbasisfraktur. Deutsche Medizinische Wochenschrift 1918441261.

9 Benvenga S. The history of pituitary dysfunction after traumatic brain injury. Pituitary 201922 229-235. (https://doi.org/10.1007/ s11102-019-00949-9)

10 Schneider HJ, Kreitschmann-Andermahr I, Ghigo E, Stalla GK \& Agha A. Hypothalamopituitary dysfunction following traumatic brain injury and aneurysmal subarachnoid hemorrhage: a systematic review. Journal of the American Medical Association 2007298 1429-1438. (https://doi.org/10.1001/jama.298.12.1429)

11 Tan CL, Alavi SA, Baldeweg SE, Belli A, Carson A, Feeney C, Goldstone AP, Greenwood R, Menon DK, Simpson HL, et al. The screening and management of pituitary dysfunction following traumatic brain injury in adults: British Neurotrauma Group Guidance. Journal of Neurology, Neurosurgery, and Psychiatry 201788 971-981. (https://doi.org/10.1136/jnnp-2016-315500)

12 Kokshoorn NE, Wassenaar MJE, Biermasz NR, Roelfsema F, Smit JWA, Romijn JA \& Pereira AM. Hypopituitarism following traumatic brain injury: prevalence is affected by the use of different dynamic tests and different normal values. European Journal of Endocrinology 2010 162 11-18. (https://doi.org/10.1530/EJE-09-0601)

13 Zheng P, He B \& Tong W. Dynamic pituitary hormones change after traumatic brain injury. Neurology India 201462 280-284. (https://doi. org/10.4103/0028-3886.136922)

14 Bondanelli M, De Marinis L, Ambrosio MR, Monesi M, Valle D, Zatelli MC, Fusco A, Bianchi A, Farneti M \& degli Uberti ECI. Occurrence of pituitary dysfunction following traumatic brain injury. Journal of Neurotrauma 200421 685-696. (https://doi. org/10.1089/0897715041269713)

15 Popovic V, Aimaretti G, Casanueva FF \& Ghigo E. Hypopituitarism following traumatic brain injury. Growth Hormone and IGF Research 200515 177-184. (https://doi.org/10.1016/j.ghir.2005.02.003)

16 Schneider M, Schneider HJ \& Stalla GK. Anterior pituitary hormone abnormalities following traumatic brain injury. Journal of Neurotrauma 200522 937-946. (https://doi.org/10.1089/neu.2005.22.937)

17 Heather N \& Cutfield W. Traumatic brain injury: is the pituitary out of Harm's way? Journal of Pediatrics 2011159 686-690. (https://doi. org/10.1016/j.jpeds.2011.05.054)

18 Dubourg J \& Messerer M. Sports-related chronic repetitive head trauma as a cause of pituitary dysfunction. Neurosurgical Focus 2011 31 E2. (https://doi.org/10.3171/2011.8.FOCUS11182)

19 Richmond E \& Rogol AD. Traumatic brain injury: endocrine consequences in children and adults. Endocrine 201445 3-8. (https:// doi.org/10.1007/s12020-013-0049-1)

20 Salehi F, Kovacs K, Scheithauer BW, Pfeifer EA \& Cusimano M. Histologic study of the human pituitary gland in acute traumatic brain injury. Brain Injury 200721 651-656. (https://doi. org/10.1080/02699050701426956)

21 Daniel PM, Prichard MM \& Treip CS. Traumatic infarction of the anterior lobe of the pituitary gland. Lancet 19592 927-931. (https:// doi.org/10.1016/s0140-6736(59)91583-1)

22 Ceballos R. Pituitary changes in head trauma (analysis of 102 consecutive cases of head injury). Alabama Journal of Medical Sciences 19663 185-198.

23 Sheehan HL. Post-partum necrosis of the anterior pituitary. Journal of Pathology and Bacteriology 193745 189-214. (https://doi.org/10.1002/ path.1700450118)

24 Gilis-Januszewska A, Kluczyński Ł, Wilusz M, Pantofliński J Turek-Jabrocka R, Pach D \& Hubalewska-Dydejczyk A. Pituitary insufficiency following traumatic thoracic injury in an adolescent male patient. Medicine 201796 e8406. (https://doi.org/10.1097/ MD.0000000000008406)

25 Kato K, Nobori M, Miyauchi Y, Ohnisi M, Yoshida S, Oya S, Tomita S \& Kino T. Pituitary apoplexy after subtotal thyroidectomy in an acromegalic patient with a large goiter. Internal Medicine 199635 472-477. (https://doi.org/10.2169/internalmedicine.35.472)

26 Hidiroglu M, Kucuker A, Ucaroglu E, Kucuker SA \& Sener E. Pituitary apoplexy after cardiac surgery. Annals of Thoracic Surgery 201089 1635-1637. (https://doi.org/10.1016/j.athoracsur.2009.09.038)

27 Yoshino M, Sekine Y, Koh E, Hata A \& Hashimoto N. Pituitary apoplexy after surgical treatment of lung cancer. Annals of Thoracic Surgery 201498 1830-1832. (https://doi.org/10.1016/j. athoracsur.2013.12.056)

28 Bavisetty S, Bavisetty S, McArthur DL, Dusick JR, Wang C, Cohan P, Boscardin WJ, Swerdloff R, Levin H, Chang DJ, et al. Chronic hypopituitarism after traumatic brain injury: risk assessment and relationship to outcome. Neurosurgery 200862 1080-1093; discussion 1093-1094. (https://doi.org/10.1227/01.neu.0000325870.60129.6a)

This work is licensed under a Creative Commons Attribution-NonCommercial-NoDerivatives 4.0 Internationab ticense.ifica com at $04 / 26 / 2023$ 08:22:08Am 
29 Krahulik D, Zapletalova J, Frysak Z \& Vaverka M. Dysfunction of hypothalamic-hypophysial axis after traumatic brain injury in adults. Journal of Neurosurgery 2010113 581-584. (https://doi. org/10.3171/2009.10.JNS09930)

30 Benvenga S, Campenní A, Ruggeri RM \& Trimarchi F. Clinical review 113: hypopituitarism secondary to head trauma. Journal of Clinical Endocrinology and Metabolism 200085 1353-1361. (https://doi. org/10.1210/jcem.85.4.6506)

31 Tan H, Yang W, Wu C, Liu B, Lu H, Wang H \& Yan H. Assessment of the role of intracranial hypertension and stress on hippocampal cell apoptosis and hypothalamic-pituitary dysfunction after TBI. Scientific Reports 20177 1-12. (https://doi.org/10.1038/s41598-017-04008-w)

32 Asa SL, Kovacs K \& Bilbao JM. The pars tuberalis of the human pituitary. a histologic, immunohistochemical, ultrastructural and immunoelectron microscopic analysis. Virchows Archiv 1983399 49-59. (https://doi.org/10.1007/bf00666218)

33 Larkin S \& Ansorge O. Development and microscopic anatomy of the pituitary gland. In Endotext. Eds KR Feingold, B Anawalt, A Boyce, G Chrousos, K Dungan, A Grossman, JM Hershman, G Kaltsas, C Koch, P Kopp, et al. South Dartmouth, MA, USA: MDText.com, Inc., 2000. (available at: https://www.ncbi.nlm.nih.gov/books/NBK425703/)

34 Dusick JR, Wang C, Cohan P, Swerdloff R \& Kelly DF. Pathophysiology of hypopituitarism in the setting of brain injury. Pituitary 201215 2-9. (https://doi.org/10.1007/s11102-008-0130-6)

35 Pavlovic D, Pekic S, Stojanovic M \& Popovic V. Traumatic brain injury: neuropathological, neurocognitive and neurobehavioral sequelae. Pituitary 201922 270-282. (https://doi.org/10.1007/ s11102-019-00957-9)

36 Kasturi BS \& Stein DG. Traumatic brain injury causes long-term reduction in serum growth hormone and persistent astrocytosis in the cortico-hypothalamo-pituitary axis of adult male rats. Journal of Neurotrauma 200926 1315-1324. (https://doi.org/10.1089/ neu.2008.0751)

37 Osterstock G, El Yandouzi T, Romanò N, Carmignac D, Langlet F, Coutry N, Guillou, A, Schaeffer M, Chauvet N, Vanacker C, et al. Sustained alterations of hypothalamic tanycytes during posttraumatic hypopituitarism in male mice. Endocrinology 2014155 1887-1898. (https://doi.org/10.1210/en.2013-1336)

38 Tanriverdi F, De Bellis A, Teksahin H, Alp E, Bizzarro A, Sinisi AA, Bellastella G, Paglionico VA, Bellastella A, Unluhizarci K, et al. Prospective investigation of pituitary functions in patients with acute infectious meningitis: is acute meningitis induced pituitary dysfunction associated with autoimmunity? Pituitary 201215 579-588. (https://doi.org/10.1007/s11102-011-0371-7)

39 Tanriverdi F, Unluhizarci K \& Kelestrimur F. Persistent neuroinflammation may be involved in the pathogenesis of traumatic brain injury (TBI)-induced hypopituitarism: potential genetic and autoimmune factors. Journal of Neurotrauma 201027 301-302. (https://doi.org/10.1089/neu.2009.1102)

40 Papa L, Lewis LM, Falk JL, Zhang Z, Silvestri S, Giordano P, Brophy GM, Demery JA, Dixit NK, Ferguson I, et al. Elevated levels of serum glial fibrillary acidic protein breakdown products in mild and moderate traumatic brain injury are associated with intracranial lesions and neurosurgical intervention. Annals of Emergency Medicine 201259 471-483. (https://doi.org/10.1016/j. annemergmed.2011.08.021)

41 Tanriverdi F, De Bellis A, Bizzarro A, Sinisi AA, Bellastella G, Pane E, Bellastella A, Unluhizarci K, Selcuklu A, Casanueva FF, et al. Antipituitary antibodies after traumatic brain injury: is head traumainduced pituitary dysfunction associated with autoimmunity? European Journal of Endocrinology 2008159 7-13. (https://doi. org/10.1530/EJE-08-0050)

42 Tanriverdi F, Unluhizarci K, Kocyigit I, Tuna IS, Karaca Z, Durak AC, Selcuklu A, Casanueva FF \& Kelestimur F. Brief communication: pituitary volume and function in competing and retired male boxers. Annals of Internal Medicine 2008148 827-831. (https://doi. org/10.7326/0003-4819-148-11-200806030-00005)

43 Tanriverdi F, De Bellis A, Ulutabanca H, Bizzarro A, Sinisi AA, Bellastella G, Amoresano Paglionico V, Dalla Mora L, Selcuklu A, Unluhizarci $\mathrm{K}$, et al. A five year prospective investigation of anterior pituitary function after traumatic brain injury: is hypopituitarism long-term after head trauma associated with autoimmunity? Journal of Neurotrauma 201330 1426-1433. (https://doi.org/10.1089/ neu.2012.2752)

44 Tanriverdi F, De Bellis A, Battaglia M, Bellastella G, Bizzarro A, Sinis AA, Bellastella A, Unluhizarci K, Selcuklu A, Casanueva FF, et al. Investigation of antihypothalamus and antipituitary antibodies in amateur boxers: is chronic repetitive head trauma-induced pituitary dysfunction associated with autoimmunity? European Journal of Endocrinology 2010162 861-867. (https://doi.org/10.1530/EJE-091024)

45 De Bellis A, Kelestimur F, Sinisi AA, Ruocco G, Tirelli G, Battaglia M, Bellastella G, Conzo G, Tanriverdi F, Unluhizarci K, et al. Antihypothalamus and anti-pituitary antibodies may contribute to perpetuate the hypopituitarism in patients with Sheehan's syndrome. European Journal of Endocrinology 2008158 147-152. (https://doi. org/10.1530/EJE-07-0647)

46 Terrell TR, Abramson R, Barth JT, Bennett E, Cantu RC, Sloane R, Laskowitz DT, Erlanger DM, McKeag D, Nichols G, et al. Genetic polymorphisms associated with the risk of concussion in 1056 college athletes: a multicentre prospective cohort study. British Journal of Sports Medicine 201852 192-198. (https://doi.org/10.1136/ bjsports-2016-097419)

47 Tanriverdi F, Taheri S, Ulutabanca H, Caglayan AO, Ozkul Y, Dundar M, Selcuklu A, Unluhizarci K, Casanueva FF \& Kelestimur F. Apolipoprotein E3/E3 genotype decreases the risk of pituitary dysfunction after traumatic brain injury due to various causes: preliminary data. Journal of Neurotrauma 200825 1071-1077. (https://doi.org/10.1089/neu.2007.0456)

48 Taheri S, Tanriverdi F, Zararsiz G, Elbuken G, Ulutabanca H, Karaca Z, Selcuklu A, Unluhizarci K, Tanriverdi K \& Kelestimur F. Circulating microRNAs as potential biomarkers for traumatic brain injuryinduced hypopituitarism. Journal of Neurotrauma 201633 1818-1825. (https://doi.org/10.1089/neu.2015.4281)

49 McCrory P, Feddermann-Demont N, Dvořák J, Cassidy JD, McIntosh A, Vos PE, Echemendia RJ, Meeuwisse W \& Tarnutzer AA. What is the definition of sports-related concussion: a systematic review. British Journal of Sports Medicine 201751 877-887. (https:// doi.org/10.1136/bjsports-2016-097393)

50 Bakhos LL, Lockhart GR, Myers R \& Linakis JG. Emergency department visits for concussion in young child athletes. Pediatrics 2010126 e550-e556. (https://doi.org/10.1542/peds.2009-3101)

51 Bazarian JJ, McClung J, Shah MN, Cheng YT, Flesher W \& Kraus J. Mild traumatic brain injury in the United States, 1998-2000. Brain Injury 200519 85-91. (https://doi.org/10.1080/026990504100017201 58)

52 Grady MF. Concussion in the adolescent athlete. Current Problems in Pediatric and Adolescent Health Care 201040 154-169. (https://doi. org/10.1016/j.cppeds.2010.06.002)

53 Kelestimur F, Tanriverdi F, Atmaca H, Unluhizarci K, Selcuklu A \& Casanueva FF. Boxing as a sport activity associated with isolated GH deficiency. Journal of Endocrinological investigation 200427 RC28RC32. (https://doi.org/10.1007/BF03345299)

54 Tanriverdi F, Unluhizarci K, Coksevim B, Selcuklu A, Casanueva FF \& Kelestimur F. Kickboxing sport as a new cause of traumatic brain injury-mediated hypopituitarism. Clinical Endocrinology 200766 360-366. (https://doi.org/10.1111/j.1365-2265.2006.02737.x)

55 Kelly DF, Chaloner C, Evans D, Mathews A, Cohan P, Wang C, Swerdloff R, Sim M-S, Lee J, Wright MJ, et al. Prevalence of pituitary hormone dysfunction, metabolic syndrome, and impaired quality https://ec.bioscientifica.com https://doi.org/10.1530/EC-20-0117 (c) 2020 The authors Published by Bioscientifica Ltd

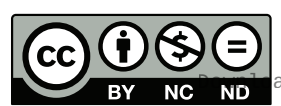

This work is licensed under a Creative Commons Attribution-NonCommercial-NoDerivatives 4.0 Internationab ticense.ifica com at $04 / 26 / 2023$ 08:22:08AM 
of life in retired professional football players: a prospective study. Journal of Neurotrauma 201431 1161-1171. (https://doi.org/10.1089/ neu.2013.3212)

56 Auer M, Stalla GK \& Athanasoulia AP. Isolated gonadotropic deficiency after multiple concussions in a professional soccer player. Deutsche Medizinische Wochenschrift 2013138 831-833. (https://doi. org/10.1055/s-0033-1343099)

57 Foley CM \& Wang DH. Central diabetes insipidus following a sportsrelated concussion: a case report. Sports Health 20124 139-141. (https://doi.org/10.1177/1941738111434275)

58 Wilkinson CW, Pagulayan KF, Petrie EC, Mayer CL, Colasurdo EA, Shofer JB, Hart KL, Hoff D, Tarabochia MA \& Peskind ER. High prevalence of chronic pituitary and target-organ hormone abnormalities after blast-related mild traumatic brain injury. Frontiers in Neurology 20123 11. (https://doi.org/10.3389/fneur.2012.00011)

59 Cernak I \& Noble-Haeusslein L. Traumatic brain injury: an overview of pathobiology with emphasis on military populations. Journal of Cerebral Blood Flow and Metabolism 200930 255-266. (https://doi. org $/ 10.1038 / \mathrm{jcbfm} .2009 .203$ )

60 Goldstein LE, Fisher AM, Tagge CA, Zhang XL, Velisek L, Sullivan JA, Upreti C, Kracht JM, Ericsson M, Wojnarowicz MW, et al. Chronic traumatic encephalopathy in blast-exposed military veterans and a blast neurotrauma mouse model. Science Translational Medicine 2012 4 134ra60. (https://doi.org/10.1126/scitranslmed.3003716)

61 Ioachimescu AG, Hampstead BM, Moore A, Burgess E \& Phillips LS Growth hormone deficiency after mild combat-related traumatic brain injury. Pituitary 201518 535-541. (https://doi.org/10.1007/ s11102-014-0606-5)

62 Undurti A, Colasurdo EA, Sikkema CL, Schultz JS, Peskind ER, Pagulayan KF \& Wilkinson CW. Chronic hypopituitarism associated with increased postconcussive symptoms is prevalent after blastinduced mild traumatic brain injury. Frontiers in Neurology 2018972 (https://doi.org/10.3389/fneur.2018.00072)

63 Baxter D, Sharp DJ, Feeney C, Papadopoulou D, Ham TE, Jilka S, Hellyer PJ, Patel MC, Bennett AN, Mistlin A, et al. Pituitary dysfunction after blast traumatic brain injury: the UK BIOSAP Study. Annals of Neurology $2013 \mathbf{7 4}$ 527-536. (https://doi.org/10.1002/ ana.23958)

64 Personnier C, Crosnier H, Meyer P, Chevignard M, Flechtner I, Boddaert N, Breton S, Mignot C, Dassa Y, Souberbielle J-C, et al. Prevalence of pituitary dysfunction after severe traumatic brain injury in children and adolescents: a large prospective study. Journal of Clinical Endocrinology and Metabolism 201499 2052-2060. (https:// doi.org/10.1210/jc.2013-4129)

65 Heather NL, Jefferies C, Hofman PL, Derraik JGB, Brennan C, Kelly P, Hamill JKM, Jones RG, Rowe DL \& Cutfield WS. Permanent hypopituitarism is rare after structural traumatic brain injury in early childhood. Journal of Clinical Endocrinology and Metabolism 201297 599-604. (https://doi.org/10.1210/jc.2011-2284)

66 Casano-Sancho P, Suárez L, Ibáñez L, García-Fructuoso G, Medina J $\&$ Febrer A. Pituitary dysfunction after traumatic brain injury in children: is there a need for ongoing endocrine assessment? Clinical Endocrinology 201379 853-858. (https://doi.org/10.1111/cen.12237)

67 Bellone S, Einaudi S, Caputo M, Prodam F, Busti A, Belcastro S, Parlamento S, Zavattaro M, Verna F, Bondone C, et al. Measurement of height velocity is an useful marker for monitoring pituitary function in patients who had traumatic brain injury. Pituitary 2013 16 499-506. (https://doi.org/10.1007/s11102-012-0446-0)

68 Jourdan C, Brugel D, Hubeaux K, Toure H, Laurent-Vannier A, \& Chevignard $\mathrm{M}$. Weight gain after childhood traumatic brain injury: a matter of concern. Developmental Medicine and Child Neurology 2012 54 624-628. (https://doi.org/10.1111/j.1469-8749.2012.04291.x)

69 Soliman AT, Adel A, Soliman NA, Elalaily R \& De Sanctis V. Pituitary deficiency following traumatic brain injury in early childhoof: a review of the literature. Georgian Medical News 2015 244-245 62-71.
70 Greco T, Hovda D \& Prins M. The effects of repeat traumatic brain injury on the pituitary in adolescent rats. Journal of Neurotrauma 201330 1983-1990. (https://doi.org/10.1089/neu.2013.2990)

71 Greco T, Hovda DA \& Prins ML. Adolescent TBI-induced hypopituitarism causes sexual dysfunction in adult male rats. Developmental Neurobiology 201575 193-202. (https://doi. org/10.1002/dneu.22218)

72 Ives JC, Alderman M \& Stred SE. Hypopituitarism after multiple concussions: a retrospective case study in an adolescent male. Journal of Athletic Training $2007 \mathbf{4 2}$ 431-439.

73 Masel BE \& DeWitt DS. Traumatic brain injury: a disease process, not an event. Journal of Neurotrauma 201027 1529-1540. (https://doi. org/10.1089/neu.2010.1358)

74 Caputo M, Mele C, Prodam F, Marzullo P \& Aimaretti G. Clinical picture and the treatment of TBI-induced hypopituitarism. Pituitary 201922 261-269. (https://doi.org/10.1007/s11102-019-00956-w)

75 Park KD, Kim DY, Lee JK, Nam HS \& Park YG. Anterior pituitary dysfunction in moderate-to-severe chronic traumatic brain injury patients and the influence on functional outcome. Brain Injury 2010 24 1330-1335. (https://doi.org/10.3109/02699052.2010.506863)

76 Klose M, Watt T, Brennum J \& Feldt-Rasmussen U. Posttraumatic hypopituitarism is associated with an unfavorable body composition and lipid profile, and decreased quality of life 12 months after injury. Journal of Clinical Endocrinology and Metabolism 200792 3861-3868. (https://doi.org/10.1210/jc.2007-0901)

77 Prodam F, Gasco V, Caputo M, Zavattaro M, Pagano L, Marzullo P, Belcastro S, Busti A, Perino C, Grottoli S, et al. Metabolic alterations in patients who develop traumatic brain injury (TBI)-induced hypopituitarism. Growth Hormone and IGF Research 201323 109-113. (https://doi.org/10.1016/j.ghir.2013.04.001)

78 Molaie AM \& Maguire J. Neuroendocrine abnormalities following traumatic brain injury: an important contributor to neuropsychiatric sequelae. Frontiers in Endocrinology 20189 176. (https://doi. org/10.3389/fendo.2018.00176)

79 Prodam F, Caputo M, Belcastro S, Garbaccio V, Zavattaro M, Samà MT, Bellone S, Pagano L, Bona G \& Aimaretti G. Quality of life, mood disturbances and psychological parameters in adult patients with GH deficiency. Panminerva Medica 201254 323-331.

80 Tanriverdi F, Ulutabanca H, Unluhizarci K, Selcuklu A, Casanueva FF \& Kelestimur F. Pituitary functions in the acute phase of traumatic brain injury: are they related to severity of the injury or mortality? Brain Injury 200721 433-439. (https://doi. org/10.1080/02699050701311083)

81 Desouza LA, Ladiwala U, Daniel SM, Agashe S, Vaidya RA \& Vaidya VA. Thyroid hormone regulates hippocampal neurogenesis in the adult rat brain. Molecular and Cellular Neurosciences 200529 414-426. (https://doi.org/10.1016/j.mcn.2005.03.010)

82 Cherrier MM, Matsumoto AM, Amory JK, Ahmed S, Bremner W, Peskind ER, Raskind MA, Johnson M \& Craft S. The role of aromatization in testosterone supplementation: effects on cognition in older men. Neurology 200564 290-296. (https://doi. org/10.1212/01.WNL.0000149639.25136.CA)

83 Jellinger KA. Traumatic brain injury as a risk factor for Alzheimer's disease. Journal of Neurology, Neurosurgery, and Psychiatry 200475 511-512.

84 Genazzani AR, Pluchino N, Luisi S \& Luisi M. Estrogen, cognition and female ageing. Human Reproduction Update 200713 175-187. (https://doi.org/10.1093/humupd/dml042)

85 Kelly DF, McArthur DL, Levin H, Swimmer S, Dusick JR, Cohan P, Wang C \& Swerdloff R. Neurobehavioral and quality of life changes associated with growth hormone insufficiency after complicated mild, moderate, or severe traumatic brain injury. Journal of Neurotrauma 200623 928-942. (https://doi.org/10.1089/neu.2006.23.928)

86 León-Carrión J, Leal-Cerro A, Cabezas FM, Atutxa AM, Gomez SG, Cordero JMF, Moreno AS, Ferrari MDR \& Domínguez-Morales MR. https://ec.bioscientifica.com https://doi.org/10.1530/EC-20-0117 (c) 2020 The authors Published by Bioscientifica Ltd
This work is licensed under a Creative Commons Attribution-NonCommercial-NoDerivatives 4.0 Internationab ticense.ifica com at $04 / 26 / 2023 \quad 08: 22: 08 \mathrm{AM}$ 
Cognitive deterioration due to gh deficiency in patients with traumatic brain injury: a preliminary report. Brain Injury $2007 \mathbf{2 1}$ 871-875. (https://doi.org/10.1080/02699050701484849)

87 Pavlovic D, Pekic S, Stojanovic M, Zivkovic V, Djurovic B Jovanovic V, Miljic N, Medic-Stojanoska M, Doknic M, Miljic D, et al. Chronic cognitive sequelae after traumatic brain injury are not related to growth hormone deficiency in adults. European Journal of Neurology 201017 696-702. (https://doi.org/10.1111/j.14681331.2009.02910.x)

88 Popovic V, Pekic S, Pavlovic D, Maric N, Jasovic-Gasic M, Djurovic B, Medic Stojanoska M, Zivkovic V, Stojanovic M, Doknic M, et al. Hypopituitarism as a consequence of traumatic brain injury (TBI) and its possible relation with cognitive disabilities and mental distress. Journal of Endocrinological Investigation 200427 1048-1054. (https://doi.org/10.1007/bf03345308)

89 Westwood AJ, Beiser A, Decarli C, Harris TB, Chen TC, He XM, Roubenoff R, Pikula A, Au R, Braverman LE, et al. Insulinlike growth factor-1 and risk of Alzheimer dementia and brain atrophy. Neurology 201482 1613-1619. (https://doi.org/10.1212/ WNL.0000000000000382)

90 Maric NP, Doknic M, Pavlovic D, Pekic S, Stojanovic M, JasovicGasic M \& Popovic V. Psychiatric and neuropsychological changes in growth hormone-deficient patients after traumatic brain injury in response to growth hormone therapy. Journal of Endocrinological Investigation 201033 770-775. (https://doi.org/10.1007/BF03350340)

91 Gardner CJ, Mattsson AF, Daousi C, Korbonits M, KoltowskaHaggstrom M \& Cuthbertson DJ. GH deficiency after traumatic brain injury: improvement in quality of life with GH therapy: analysis of the KIMS database. European Journal of Endocrinology 2015172 371-381. (https://doi.org/10.1530/EJE-14-0654)

92 Tanriverdi F, Kocyigit I, Unluhizarci K, Casanueva F \& Kelestimur F. Body Composition, serum IGF-I and leptin level changes in amateur boxers: retired boxers have risk factors for cardiovascular disorders. Obesity and Metabolism 20084 118-123.

93 Hannon MJ, Crowley RK, Behan LA, O'Sullivan EP, O’Brien MMC, Sherlock M, Rawluk D, O’Dwyer R, Tormey W \& Thompson CJ. Acute glucocorticoid deficiency and diabetes insipidus are common after acute traumatic brain injury and predict mortality. Journal of Clinical Endocrinology and Metabolism 201398 3229-3237. (https:// doi.org/10.1210/jc.2013-1555)

94 Bensalah M, Donaldson M, Aribi Y, Iabassen M, Cherfi L, Nebbal M, Medjaher M, Haffaf E, Abdennebi B, Guenane K, et al. Cortisol evaluation during the acute phase of traumatic brain injury-a prospective study. Clinical Endocrinology 201888 627-636. (https:// doi.org/10.1111/cen.13562)

95 Cohan P, Wang C, McArthur DL, Cook SW, Dusick JR, Armin B, Swerdloff R, Vespa P, Muizelaar JP, Cryer HG, et al. Acute secondary adrenal insufficiency after traumatic brain injury: a prospective study. Critical Care Medicine 200533 2358-2366. (https://doi org/10.1097/01.ccm.0000181735.51183.a7)

96 Simmons AN \& Matthews SC. Neural circuitry of PTSD with or without mild traumatic brain injury: a meta-analysis. Neuropharmacology 201262 598-606. (https://doi.org/10.1016/j. neuropharm.2011.03.016)

97 Temizkan S \& Kelestimur F. A Clinical and pathophysiological approach to traumatic brain injury-induced pituitary dysfunction. Pituitary 2019 22 220-228. (https://doi.org/10.1007/s11102-019-00941-3)

98 Tanriverdi F, Senyurek H, Unluhizarci K, Selcuklu A, Casanueva FF $\&$ Kelestimur F. High risk of hypopituitarism after traumatic brain injury: a prospective investigation of anterior pituitary function in the acute phase and 12 months after trauma. Journal of Clinical Endocrinology and Metabolism 200691 2105-2111. (https://doi. org/10.1210/jc.2005-2476)

99 Gasco V, Prodam F, Pagano L, Grottoli S, Belcastro S, Marzullo P, Beccuti G, Ghigo E \& Aimaretti G. Hypopituitarism following brain injury: when does it occur and how best to test? Pituitary 201215 20-24. (https://doi.org/10.1007/s11102-010-0235-6)

100 Lauzier F, Turgeon AF, Boutin A, Shemilt M, Côté I, Lachance O, Archambault PM, Lamontagne F, Moore L, Bernard F, et al. Clinical outcomes, predictors, and prevalence of anterior pituitary disorders following traumatic brain injury: a systematic review. Critical Care Medicine 201442 712-721. (https://doi.org/10.1097/ CCM.0000000000000046)

101 Glynn N \& Agha A. Which patient requires neuroendocrine assessment following traumatic brain injury, when and how? Clinical Endocrinology 201378 17-20. (https://doi.org/10.1111/ cen.12010)

102 Agha A, Thornton E, O'Kelly P, Tormey W, Phillips J \& Thompson CJ. Posterior pituitary dysfunction after traumatic brain injury. Journal of Clinical Endocrinology and Metabolism 200489 5987-5992. (https:// doi.org/10.1210/jc.2004-1058)

103 Hadjizacharia P, Beale EO, Inaba K, Chan LS \& Demetriades D. Acute diabetes insipidus in severe head injury: a prospective study. Journal of the American College of Surgeons 2008207 477-484. (https://doi. org/10.1016/j.jamcollsurg.2008.04.017)

104 Smith D, McKenna K, Moore K, Tormey W, Finucane J, Phillips J, Baylis P \& Thompson CJ. Baroregulation of vasopressin release in adipsic diabetes insipidus. Journal of Clinical Endocrinology and Metabolism 200287 4564-4568. (https://doi.org/10.1210/jc.2002020090)

105 Glynn N \& Agha A. The frequency and the diagnosis of pituitary dysfunction after traumatic brain injury. Pituitary 201922 249-260. (https://doi.org/10.1007/s11102-019-00938-y)

106 Hannon MJ, Finucane FM, Sherlock M, Agha A \& Thompson CJ. Clinical review: disorders of water homeostasis in neurosurgical patients. Journal of Clinical Endocrinology and Metabolism 201297 1423-1433. (https://doi.org/10.1210/jc.2011-3201)

107 Tritos NA, Yuen KCJ, Kelly DF \& AACE Neuroendocrine and Pituitary Scientific Committee. American Association of Clinical Endocrinologists and American College of Endocrinology Disease State Clinical Review: a neuroendocrine approach to patients with traumatic brain injury. Endocrine Practice 201521 823-831. (https:// doi.org/10.4158/EP14567.DSCR)

108 Agha A, Tomlinson JW, Clark PM, Holder G \& Stewart PM. The long-term predictive accuracy of the short synacthen (Corticotropin) stimulation test for assessment of the hypothalamic-pituitary-adrenal axis. Journal of Clinical Endocrinology and Metabolism 200691 43-47. (https://doi.org/10.1210/jc.2005-1131)

109 Molitch ME, Clemmons DR, Malozowski S, Merriam GR, Vance ML \& Endocrine Society. Evaluation and treatment of adult growth hormone deficiency: an Endocrine Society Clinical Practice Guideline. Journal of Clinical Endocrinology and Metabolism. 201196 1587-1609. (https://doi.org/10.1210/jc.2011-0179)

110 Dichtel LE, Yuen KCJ, Bredella MA, Gerweck AV, Russell BM, Riccio AD, Gurel MH, Sluss PM, Biller BMK \& Miller KK. Overweight/ obese adults with pituitary disorders require lower peak growth hormone cutoff values on glucagon stimulation testing to avoid overdiagnosis of growth hormone deficiency. Journal of Clinical Endocrinology and Metabolism 201499 4712-4719. (https://doi. org/10.1210/jc.2014-2830)

111 Czeiter E, Mondello S, Kovacs N, Sandor J, Gabrielli A, Schmid K, Tortella F, Wang KK, Hayes RL, Barzo P, et al. Brain injury biomarkers may improve the predictive power of the IMPACT outcome calculator. Journal of Neurotrauma 201229 1770-1778. (https://doi. org/10.1089/neu.2011.2127)

112 Toth A. Magnetic resonance imaging application in the area of mild and acute traumatic brain injury: implications for diagnostic markers? In Brain Neurotrauma: Molecular, Neuropsychological, and Rehabilitation Aspects. Ed FH Kobeissy; Frontiers in Neuroengineering. Boca Raton, FL, USA: CRC Press/Taylor \& Francis, 2015. https://ec.bioscientifica.com

https://doi.org/10.1530/EC-20-0117
(C) 2020 The authors Published by Bioscientifica Ltd
This work is licensed under a Creative Commons Attribution-NonCommercial-NoDerivatives 4.0 Internationab sicense.ifica . com at 04/26/2023 08:22:08AM 
113 Haghbayan H, Boutin A, Laflamme M, Lauzier F, Shemilt M, Moore L, Zarychanski R, Douville V, Fergusson D \& Turgeon AF. The Prognostic value of MRI in moderate and severe traumatic brain injury: a systematic review and meta-analysis. Critical Care Medicine $2017 \mathbf{4 5}$ e1280-e1288. (https://doi.org/10.1097/CCM.0000000000002731)

114 Kelly DF, Gonzalo IT, Cohan P, Berman N, Swerdloff R \& Wang C. Hypopituitarism following traumatic brain injury and aneurysmal subarachnoid hemorrhage: a preliminary report. Journal of Neurosurgery 200093 743-752. (https://doi.org/10.3171/ jns.2000.93.5.0743)

115 Schneider M, Schneider HJ, Yassouridis A, Saller B, von Rosen F \& Stalla GK. Predictors of anterior pituitary insufficiency after traumatic brain injury. Clinical Endocrinology 200868 206-212. (https://doi.org/10.1111/j.1365-2265.2007.03020.x)

116 De Marinis L, Bonadonna S, Bianchi A, Maira G \& Giustina A. Primary empty sella. Journal of Clinical Endocrinology and Metabolism 200590 5471-5477. (https://doi.org/10.1210/jc.2005-0288)

117 Ozdemir D, Baykara B, Aksu I, Kiray M, Sisman AR, Cetin F, Dayi A, Gurpinar T, Uysal N \& Arda MN. Relationship between circulating IGF-1 levels and traumatic brain injury-induced hippocampal damage and cognitive dysfunction in immature rats. Neuroscience Letters 2012507 84-89. (https://doi.org/10.1016/j. neulet.2011.11.059)

118 Melmed S. Mechanisms for pituitary tumorigenesis: the plastic pituitary. Journal of Clinical Investigation 2003112 1603-1618. (https://doi.org/10.1172/JCI20401)

119 Schneider HJ, Sämann PG, Schneider M, Croce CG, Corneli G, Sievers C, Ghigo E, Stalla GK \& Aimaretti G. Pituitary imaging abnormalities in patients with and without hypopituitarism after traumatic brain injury. Journal of Endocrinological Investigation 2007 30 RC9-RC12. (https://doi.org/10.1007/BF03346291)
120 Schneider HJ, Aimaretti G, Kreitschmann-Andermahr I, Stalla GK, Ghigo E. Hypopituitarism. Lancet 2007369 1461-1470. (https://doi. org/10.1016/S0140-6736(07)60673-4)

121 Tanriverdi F, Schneider HJ, Aimaretti G, Masel BE, Casanueva FF \& Kelestimur F. Pituitary dysfunction after traumatic brain injury: a clinical and pathophysiological approach. Endocrine Reviews 201536 305-342. (https://doi.org/10.1210/er.2014-1065)

122 Quinn M \& Agha A. Post-traumatic hypopituitarism-who should be screened, when, and how? Frontiers in Endocrinology 201898. (https://doi.org/10.3389/fendo.2018.00008)

123 Moreau OK, Cortet-Rudelli C, Yollin E, Merlen E, Daveluy W \& Rousseaux M. Growth hormone replacement therapy in patients with traumatic brain injury. Journal of Neurotrauma $2013 \mathbf{3 0}$ 998-1006. (https://doi.org/10.1089/neu.2012.2705)

124 Klose M, Juul A, Struck J, Morgenthaler NG, Kosteljanetz M \& FeldtRasmussen U. Acute and long-term pituitary insufficiency in traumatic brain injury: a prospective single-centre study. Clinical Endocrinology 200767 598-606. (https://doi.org/10.1111/j.1365-2265.2007.02931.x)

125 Agha A, Phillips J, O'Kelly P, Tormey W, Thompson CJ. The natural history of post-traumatic hypopituitarism: implications for assessment and treatment. American Journal of Medicine 2005118 1416. (https://doi.org/10.1016/j.amjmed.2005.02.042)

126 Fernandez-Rodriguez E, Bernabeu I, Castro AI \& Casanueva FF. Hypopituitarism after traumatic brain injury. Endocrinology and Metabolism Clinics of North America 201544 151-159. (https://doi. org/10.1016/j.ecl.2014.10.012)

127 Herrmann BL, Rehder J, Kahlke S, Wiedemayer H, Doerfler A, Ischebeck W, Laumer R, Forsting M, Stolke D, Mann K. Hypopituitarism following severe traumatic brain injury. Experimental and Clinical Endocrinology and Diabetes 2006114 316-321. (https:// doi.org/10.1055/s-2006-924254)

Received in final form 8 April 2020

Accepted 21 April 2020

Accepted Manuscript published online 21 April 2020 https://ec.bioscientifica.com https://doi.org/10.1530/EC-20-0117 (c) 2020 The authors Published by Bioscientifica Ltd
This work is licensed under a Creative Commons Attribution-NonCommercial-NoDerivatives 4.0 Internationab sicense.ifica . com at 04/26/2023 08:22:08AM 